\title{
EVALUASI KOMPETENSI PELATIH SEPAKBOLA USIA DINI DI SEKOLAH SEPAKBOLA
}

\author{
Ujang Rohman ${ }^{1 *}$ \\ ${ }^{1}$ Program Studi Pendidikan Kepelatihan Olahraga \\ FKIP Universitas PGRI Adi Buana Surabaya \\ email: ujang_roh64@unipasby.ac.id
}

\begin{abstract}
Abstrak
Penelitian ini membahas mengenai evaluasi kompetensi pelatih sepakbola usia dini. Metode yang digunakan adalah metode kombinasi (kuantitatif-kualitatif) dengan model evaluasi CIPP. Hasil analisis data diperoleh nilai evaluasi: 1. Context. sebesar 61.66\% menunjukkan legalitas keberadaan pelatih perlu dukungan pemerintah dan lembaga terkait (Asosiasi PSSI, KONI dan Asosiasi SSB). 2. Input. sebesar 53.03\% menunjukkan pelatih harus memiliki kualifikasi akademik, pengalaman melatih dan kewenangan melatih. 3. Process. Hasil analisis SEM melalui pendekatan Partial Least Square (PLS), diketahui pengaruh kompetensi pelatih $(\mathrm{X})$ terhadap kompetensi pengembangan karakter $(\mathrm{X} 1)=26.064044$, kompetensi motivasi $(\mathrm{X} 2)=16.628261$, kompetensi teknik $(\mathrm{X} 3)=$ 34.177510 dan kompetensi strategi permainan $(\mathrm{X} 4)=26.900712$ berarti thitung $>$ ttabel $(1,96)$. Sedangkan nilai goodness of fit atau R-square (R2) variabel (X1) sebesar 0.7549, (X2) sebesar 0.7572, (X3) sebesar 0,6844 dan sebesar (X4) sebesar 0.7805 secara deskriptif menunjukkan kompetensi pelatih sepakbola usia dini ada pengaruh dan relevansinya terhadap kompetensi pengembangan karakter, kompetensi strategi permainan, kompetensi motivasi, dan kompetensi teknik. 4. Product. Kompetensi pelatih sepakbola usia dini yang direpresentasikan oleh komponen kompetensi pengembangan karakter, strategi permainan, motivasi dan kompetensi teknik secara konseptual dikembangkan menjadi tiga rumusan kompetensi pelatih terdiri dari unsur sikap (afektif), pengetahuan (kognitif), dan keterampilan (psikomotor).
\end{abstract}

Kata kunci: Kompetensi \& Pelatih Sepakbola Usia Dini

\begin{abstract}
This study discusses the competency of football coach of early age. The method used in this research is mixed (quantitative-qualitative) methods with CIPP evaluation model. The results of data obtained evaluation value: 1. Context. Analysis reveals that a variable scores of coach presence in the count of $61.66 \%$ 2. Input. Analysis shows score of $53.03 \%$ variable of human resource of the academic coaches. 3. Process. analysis a description of the evaluation process, it includes: competence of development character 59.69\%, motivation competence $55.00 \%$, technical competence $53.51 \%$ and competence of games strategy 50.00\% . The analysis of SEM through approach Partial Least Square (PLS) is known from the value of the influence competence of coach $(X)$ to character development competence $(X 1)=26.064044$, motivation competence $(X 2)=16.628261$, technical competence $(X 3)=34.177510$ and competence strategy game $(X 4)=26.900712$ means tcount $>$ ttable $(1,96)$. While the value goodness of fit or $R$-square $(R 2)$ variable $(X 1)=0.7549,(X 2)=0.6844,(X 3)=$ 0.7805 and $(X 4)=0.7572$. Shows that all indicators represent variables of coach competencies which describe the significant influence, that the competence of football coach of early age has relevance. 4. Product. The competence of early-age football coach represented by the competence component of character development, game strategy, motivation and technical competence are conceptually developed into three competence formulas of trainers consisting of attitudes (affective), knowledge (cognitive), and skills (psychomotor).
\end{abstract}

Keywords: Competence \& Football Coach An Early Age. 


\section{PENDAHULUAN}

Memaknai pelatih sebagai salah satu indikator keberhasilan atlet meraih prestasi, bila dilihat dari prestasi yang dicapai tim sepakbola Indonesia beberapa tahun terakhir di pertandingan resmi multievent antar negara belum mencapai prestasi optimal. Prestasi yang dicapai tim sepakbola Indonesia di Asia Tenggara sejak tahun 1996 sampai dengan tahun 2004 belum pernah berhasil mencapai juara Piala Tiger. Kemudian pada tahun 2007 sampai dengan sekarang, sejak Piala Tiger berubah menjadi Piala Suzuki AFF (Asean Football Federation Cup) tim sepakbola Indonesia belum pernah berhasil mencapai juara. Selama keikutsertaan tim sepakbola Indonesia di kejuaraan sepakbola negara-negara ASEAN (Association of Southeast Asian Nation) tersebut, prestasi tertinggi Indonesia hanya mencapai tempat kedua di tahun 2000, 2002, 2004 dan 2010. Demikian juga di even pekan olahraga Asia Tenggara atau SEA Games (South East Asian Games) sejak tahun 1977 sampai dengan sekarang untuk cabang olahraga sepakbola, Indonesia hanya dua kali menjadi juara Sea Games yaitu Sea Games ke XIV tahun 1987 di Jakarta dan Sea Games ke XVI 1991 di Manila, Sedangkan berdasarkan FIFA (Federation Internationale de Football Association) World Rangkings prestasi tim sepakbola Indonesia pada tahun 2010 berada pada rangking 138, tahun 2011 rangking 129, sedangkan di tahun 2012, 2013, dan 2014 secara keseluruhan posisi Indonesia rangking 156, 170, dan 153 serta pada tahun 2015 Indonesia berada pada rangking ke 174.

Kenyataan capaian prestasi sepakbola tersebut salah satu indikatornya adalah bagaimana pelatih dapat memacu prestasi optimal pada atlet yang dilatih. Prestasi optimal dapat dipacu apabila pelatih memiliki kompetensi yang tercermin dari kemampuan pengetahuan, sikap, dan kecakapannya dalam melatih. Kompetensi pelatih secara spesifik belum ada rumusan yang standar di setiap cabang olahraga. Khusus pada cabang olahraga sepakbola, Asosiasi PSSI sebagai induk organisasi yang membawahi cabang olahraga sepakbola sampai saat ini belum mengeluarkan ketetapan mengenai standar kompetensi pelatih sepakbola. Asosiasi PSSI saat ini hanya mengeluarkan lisensi kewenangan melatih seorang pelatih, sedangkan Badan Sertifikasi dan Akreditasi Nasional Keolahragaan (BSANK) lebih berfungsi mempersiapkan perumusan kebijakan dan pelaksanaan kebijakan standarisasi, akreditasi, dan sertifikasi keolahragaan. Demikian pula para pakar dan praktisi olahraga hanya merumuskan konsep kompetensi pelatih lebih bersifat umum untuk cabang olahraga.

Atas dasar beberapa persoalan yang ada dalam persepakbolaan di Indonesia pada saat ini, peneliti tertarik untuk meneliti lebih lanjut mengenai kompetensi pelatih sepakbola usia dini. Alasan peneliti karena pembinaan pemain sepakbola usia dini merupakan pondasi yang sangat mendasar sebagai bahan penunjang kokohnya pembinaan sepakbola yang harus ditangani oleh pelatih berkompeten sesuai dengan standar kompetensinya. Harapan tersebut saat tahun 2012 telah disampaikan Ketua Umum PSSI Johar Arifin (2012) yang mengatakan: Persatuan Sepakbola Seluruh Indonesia (PSSI) akan berupaya menaikkan kompetensi pelatih untuk usia muda/anak-anak. Itu penting karena sekarang ini, pelatih untuk usia muda disamakan dengan yang untuk dewasa. Dengan peningkatan kompetensi pelatih untuk usia muda, maka bakat-bakat muda akan lebih muncul. Dan sepuluh tahun lagi, hasil pembinaan usia muda akan terlihat jelas .

Berdasarkan pendapat tersebut, yang melatar belakangi belum optimalnya prestasi persepakbolaan di Indonesia yang perlu mendapat perhatian untuk dikaji dan diteliti secara mendasar salah satunya mengenai kompetensi pelatih. Oleh karena itu dalam penelitian akan dievaluasi mengenai kompetensi pelatih sepakbola usia dini dengan pendekatan model evaluasi CIPP (context, input, process, product). Ruang lingkup penelitian ini penekanannya pada pengembangan kemampuan dan kualitas pelatih sepakbola usia dini ditinjau dari aspek kompetensi pelatih. Kompetensi pelatih yang menjadi bahan 
evaluasi terdiri dari komponen kompetensi pengembangan karakter, kompetensi strategi permainan, kompetensi motivasi, dan kompetensi teknik (Philips. 2007).

Penelitian mengenai kompetensi pelatih sepakbola, secara spesifik untuk jenjang anak usia dini belum pernah dilakukan, karena berdasarkan beberapa hasil penelitian diantaranya oleh Syafii (2007) lebih mengkaji tentang rangkaian butir tes keterampilan teknik dasar sepakbola kelompok usia dini yang valid dan reliabel". Mugiyo, dkk. (2011) tentang pola pembinaan SSB ditinjau dari sisi (1) manajemen organisasi, (2) manajemen keuangan, (3) manajemen sarana dan prasarana, (4) manajemen kepelatihan" Satria, dkk. (2012) tentang evaluasi program pembinaan sepakbola dengan di Sekayu Youth Soccer Academy (SYSA), Kabupaten Musi Banyuasin, Sumatra Selatan". Dimyati (2012) tentang pengembangan model pembelajaran fair play terintegrasi dalam proses pelatihan sepakbola usia remaja di SSB, dan Cholid (2014) tentang evaluasi pelaksanaan sekolah sepakbola (SSB) di Jawa Timur.

Berdasarkan beberapa hasil penelitian yang sudah ada, menunjukkan bahwa para peneliti terdahulu lebih menekankan pada pengembangan dan pembinaan sepakbola ditinjau dari aspek fisik, teknik, dan manajemen sepakbola, sedangkan aspek pelatih yang mengkaji tentang kompetensi pelatih secara empirik belum ada. Oleh karena itu merujuk dari hasil penelitian yang belum ada, maka penelitian ini meneliti mengenai evaluasi kompetensi pelatih sepakbola usia dini. Alasan yang mendasar dikarenakan selama ini kompetensi pelatih anak usia dini, proses pelatihan masih disamakan dengan usia dewasa, oleh karena itu dalam penelitian ini berupaya untuk mengembangkan kompetensi pelatih yang dikhususkan untuk anak usia dini. Temuan penelitian ini diharapkan dapat dijadikan dasar untuk mengembangkan dan merevisi tentang kompetensi pelatih yang didalamnya terdiri dari bagian-bagian kompetensi yang lebih spesifik untuk anak usia dini. Kajian analisis hasil evaluasi kompetensi pelatih yang dikhususkan untuk anak usia dini dapat dijadikan bahan kebijakan oleh induk organisasi sepakbola di Indonesia dalam rangka mengembangkan dan meningkatkan prestasi sepakbola nasional.

\section{METODE}

Penelitian ini menggunakan metode kombinasi (mixed methods), yaitu suatu metode penelitian yang mengkombinasikan antara metode kuantitatif dan kualitatif untuk digunakan secara bersama-sama dalam suatu kegiatan penelitian, sehingga diperoleh data yang lebih komprehensif, valid, reliabel dan obyektif (Sugiyono. 2012). Metode penelitian kombinasi menggunakan model sekuensial (sequential model) dengan desain eksplanatoris sekuensial (sequential explanatory design) melalui pendekatan model evaluasi CIPP secara komprehensif seperti pada gambar 1 berikut.

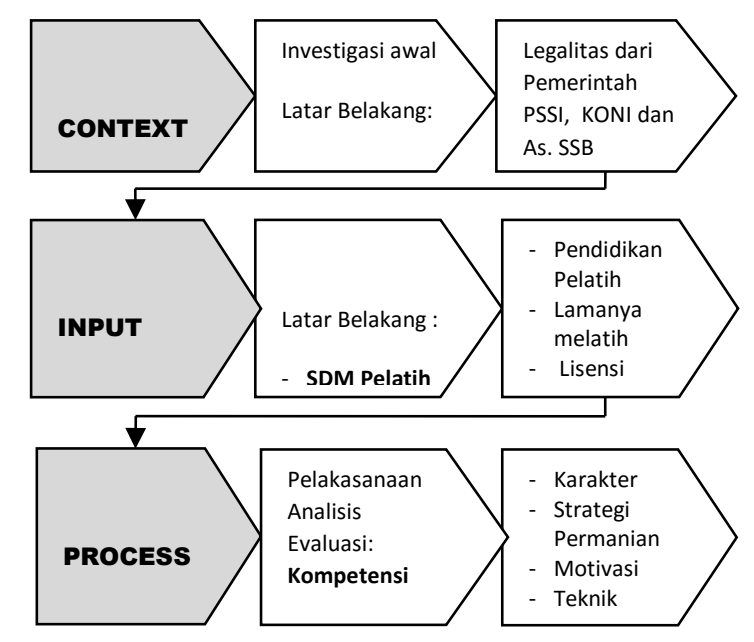

Gambar. 1. Bagan Penelitian Model Evaluasi CIPP Kompetensi Pelatih 
Teknik Pengumpulan data dilakukan dengan menggunakan dua pendekatan yaitu pendekatan kuantitatif dan kualitatif. Instrumen yang digunakan dalam bentuk kuesioner, wawancara dan obervasi

\section{Populasi}

Populasi penelitian adalah keseluruhan pelatih SSB di Asosiasi PSSI Jawa Timur, sedangkan sampel adalah pelatih sepakbola usia dini di SSB yang terdaftar di Asosiasi Kabupaten/Kota (Askab/Askot) PSSI Jawa Timur minimal lisensi D melatih berdasarkan kewenangan yang dikeluarkan oleh Asosiasi PSSI.

\section{Analisis Data Kuantitatif}

Analisis data kuantitatif menggunakan analisis statistik deskripsi persentase ( $p=\mathrm{f} / \mathrm{n} \times 100 \%)$ dan analisis model SEM (Structural Equation Modelling dengan pendekatan PLS (Partial Least Square) meliputi tahapan:

a. Model struktural atau Inner model dalam persamaan linier $\xi_{j}=\sum_{i} \beta_{j i} \xi_{i}+\zeta_{j}$ yang merupakan koefisien dari hubungan antara variabel ke-i dengan variabel ke-j (path coefficient) menggambarkan hubungan antar variabel.

b. Model pengukuran atau outer model Blok indikator reflektif persamaannya dengan regresi sederhanax $_{\mathrm{jk}}=\lambda_{\mathrm{jk}} \xi_{\mathrm{j}}+\varepsilon_{\mathrm{jk}}$ merupakan coefficient loading dari hubungan variabel ke-j dengan indikatornya ke-k merupakan residual atau error dari setiap variabel pengukuran.

c. Weight relation, nilai uji evaluasi terhadap model persamaan struktural dapat diketahui dari nilai goodness of fit atau nilai $\mathrm{R}$-square $\left(\mathrm{R}^{2}\right)$.

\section{Analisis Data Kualitatif}

Analisis data kualitatif menggunakan model interaktif (interactive model) dilakukan melalui langkahlangkah: (1) reduksi data, (2) display/ penyajian data; dan (3) mengambil kesimpulan, lalu diverifikasi. Model interaktif data menggunakan matriks yang dimulai dari; "paparan data, kemudian dikelompokan dan dikumpulkan (data collection), selanjutnya mereduksi data (data reduction) sesuai dengan bentuk datanya, setelah itu menyajikan data (data display) dan dilakukan verfikasi dengan data lainnya agar ditemukan satu bentuk kesimpulan.

\section{HASIL dan PEMBAHASAN}

\section{Uji Coba Instrumen}

Analisis uji validitas menggunakan aplikasi komputer program SPSS (Statistical Package for the Social Science) versi 21. Hasil analisis uji instrumen dari 80 item yang memiliki nilai validitas $>0.44$ sebanyak 55 item dinyatakan valid dan nilai reliabilitas Alpha Cronbach dengan nilai > $0.60-0.70$ adalah nilai terendah yang dapat diterima dinyatakan reliabel. Artinya terpenuhinya validitas dan reliabilitas instrumen, selanjutnya dapat dilakukan proses pengambilan data melalui tahapan penyebaran kuesioner, wawancara dan observasi.

\section{Hasil Analisis Data Kuantitatif}

Berdasarkan sebaran data yang terkumpul dari 60 responden selanjutnya dilakukan analisis data kuantitatif menggunakan model evaluasi CIPP yang meliputi:

1. Evaluasi context 
Hasil analisis deskriptif nilai rata-rata pada setiap indikator, secara context keberadaan pelatih sepakbola usia dini sebesar $61.66 \%$ relevansinya perlu adanya dukungan pemerintah dan lembaga terkait (KONI, PSSI dan Asosiasi SSB).

2. Evaluasi input

Hasil analisis deskriptif nilai rata-rata pada setiap indikator, secara input SDM Pelatih sepakbola usia dini sebesar $43 . .47 \%$ relevansinya SDM Pelatih harus memiliki latar belakang pendidikan, lamanya melatih dan lisensi melatih.

3. Evaluasi Process

Deskripsi kompetensi pelatih berdasarkan analisis Structural Equation Modelling (SEM) dengan Pendekatan PLS (Partial Least Square) meliputi tiga tahap yaitu:

a. Model Pengukuran (Outer Model) Hasilnya menunjukkan variabel kompetensi pengembangan karakter $\left(\mathrm{X}_{1}\right)$ yang direpresentasikan oleh 4 indikator $\left(\mathrm{X}_{1.1}, \mathrm{X}_{1.2}, \mathrm{X}_{1.3}\right.$ dan $\mathrm{X} 1.4)$, variabel kompetensi motivasi $\left(\mathrm{X}_{2}\right)$ yang direpresentasikan oleh 4 indikator $\left(\mathrm{X}_{2.1}, \mathrm{X}_{2.2}\right.$, $\mathrm{X}_{2.3}$ dan $\left.\mathrm{X}_{2.4}\right)$, variabel kompetensi teknik $\left(\mathrm{X}_{3}\right)$ yang direpresentasikan oleh 3 indikator $\left(\mathrm{X}_{3.1}\right.$, $\mathrm{X}_{3.2}$ dan $\left.\mathrm{X}_{3.3}\right)$ dan variabel kompetensi strategi permainan $\left(\mathrm{X}_{4}\right)$ direpresentasi-kan oleh 3 indikator $\left(\mathrm{X}_{4.1}, \mathrm{X}_{4.2,}\right.$, dan $\left.\mathrm{X}_{4.3}\right)$ dinyatakan valid (nilai loading factor $\left.>0.5\right)$ dan signifikan dengan $t_{\text {hitung }}>\mathrm{t}_{\text {tabel }}(>1.96)$. Hasilnya dapat dilihat pada tabel 1 berikut.

Tabel 1. Hasil Analisis Convergent Validity

\begin{tabular}{llll}
\hline Hub. & Original Sample $(\mathbf{O})$ & $\mathbf{S T D E V}$ & T Statistics $(\mid \mathbf{O} / \mathbf{S T E R R})$ \\
\hline $\mathbf{X}_{\mathbf{1 . 1}}<-\mathbf{X}_{\mathbf{1}}$ & 0.846745 & 0.04286 & 19.756018 \\
\hline $\mathbf{X}_{\mathbf{1 . 2}}<-\mathbf{X}_{\mathbf{1}}$ & 0.57137 & 0.12237 & 4.669205 \\
\hline $\mathbf{X}_{\mathbf{1 . 3}}<-\mathbf{X}_{\mathbf{1}}$ & 0.592829 & 0.134324 & 4.413422 \\
\hline $\mathbf{X}_{\mathbf{1 . 4}}<-\mathbf{X}_{\mathbf{1}}$ & 0.702655 & 0.084774 & 8.288606 \\
\hline $\mathbf{X}_{\mathbf{2 . 1}}<-\mathbf{X}_{\mathbf{2}}$ & 0.719148 & 0.087859 & 8.185283 \\
\hline $\mathbf{X}_{\mathbf{2 . 2}}<-\mathbf{X}_{\mathbf{2}}$ & 0.714683 & 0.080761 & 8.849406 \\
\hline $\mathbf{X}_{\mathbf{2 . 3}}<-\mathbf{X}_{\mathbf{2}}$ & 0.770392 & 0.068335 & 11.273761 \\
\hline $\mathbf{X}_{\mathbf{2 . 4}}<-\mathbf{X}_{\mathbf{2}}$ & 0.673219 & 0.105215 & 6.398493 \\
\hline $\mathbf{X}_{\mathbf{3 . 1}}<-\mathbf{X}_{\mathbf{3}}$ & 0.813783 & 0.043695 & 18.623971 \\
\hline $\mathbf{X}_{\mathbf{3 . 2}}<-\mathbf{X}_{\mathbf{3}}$ & 0.715287 & 0.0921 & 7.766401 \\
\hline $\mathbf{X}_{\mathbf{3 . 3}}<-\mathbf{X}_{\mathbf{3}}$ & 0.831997 & 0.051516 & 16.150331 \\
\hline $\mathbf{X}_{\mathbf{4 . 1}}<-\mathbf{X}_{\mathbf{4}}$ & 0.806156 & 0.042816 & 18.828359 \\
\hline $\mathbf{X}_{\mathbf{4 . 2}}<-\mathbf{X}_{\mathbf{4}}$ & 0.857744 & 0.04278 & 20.050213 \\
\hline $\mathbf{X}_{\mathbf{4 . 3}}<-\mathbf{X}_{\mathbf{4}}$ & 0.671737 & 0.130956 & 5.129496 \\
\hline
\end{tabular}

Hasil evaluasi composite reliability menunjukkan bahwa semua indikator yang mengukur konstruk kompetensi pelatih (X) yang meliputi variabel; komptensi pengembangan karakter $\left(\mathrm{X}_{1}\right)$, kompetensi motivasi $\left(\mathrm{X}_{2}\right)$, komptensi teknik $\left(\mathrm{X}_{3}\right)$ dan kompetensi strategi permainan $\left(\mathrm{X}_{4}\right)$ dikatakan memiliki reliabilitas yang baik, dengan nilai $>0,7$. Hasilnya dapat dilihat pada tabel 2 berikut.

Tabel 2. Hasil Analisis Composite Reliability

\begin{tabular}{lcl}
\hline Variabel & Variabel Laten & $\begin{array}{l}\text { Composite } \\
\text { Reliability }\end{array}$ \\
\hline Kompetensi Pelatih & a. Pengembangan & 0.777162 \\
$(\mathrm{X})$ & Karakter $\left(\mathrm{X}_{1}\right)$ & \\
\cline { 2 - 2 } &
\end{tabular}




\begin{tabular}{lll}
\hline Variabel & Variabel Laten & $\begin{array}{l}\text { Composite } \\
\text { Reliability }\end{array}$ \\
\hline & b. Motivasi $\left(\mathrm{X}_{2}\right)$ & 0.811335 \\
\hline c. Teknik $\left(\mathrm{X}_{3}\right)$ & 0.830976 \\
\hline $\begin{array}{c}\text { d. Strategi } \\
\text { Permainan }\left(\mathrm{X}_{4}\right)\end{array}$ & 0.824253 \\
\hline
\end{tabular}

Model Struktural (Inner Model).

Evaluasi model struktural (inner model) dilakukan untuk mengetahui hubungan antar variabel, yaitu hubungan antara kompetensi pelatih $(\mathrm{X})$ dengan kompetensi pengembangan karakter $\left(\mathrm{X}_{1}\right)$, kompetensi motivasi $\left(\mathrm{X}_{2}\right)$, kompetensi teknik $\left(\mathrm{X}_{3}\right)$, dan kompetensi strategi permainan $\left(\mathrm{X}_{4}\right)$. Estimasi model struktural hubungan kompetensi pelatih dengan variabel komponen kompetensi pelatih menunjukkan nilai $t$-hitung $>\mathrm{t}_{\text {tabel }}(>1,96)$. Hasilnya dapat dilihat pada tabel 3 berikut.

Tabel 3. Estimasi Model Hubungan Kompepetensi Pelatih

\begin{tabular}{llcl}
\hline Hub. & Original Sample $(\mathbf{O})$ & STDEV & T Statistics (|O/STERR) \\
\hline $\begin{array}{l}\mathbf{X} \\
\mathbf{X}_{\mathbf{1}}\end{array}$ & 0.868850 & 0.033335 & 26.064044 \\
\hline $\begin{array}{l}\mathbf{X} \\
\mathbf{X}_{\mathbf{2}}\end{array}$ & 0.827288 & 0.049752 & 16.628261 \\
\hline $\begin{array}{l}\mathbf{X} \\
\mathbf{X}_{\mathbf{3}}\end{array}$ & 0.883477 & 0.025850 & 34.177510 \\
\hline $\begin{array}{l}\mathbf{X} \\
\mathbf{X}_{\mathbf{4}}\end{array}$ & 0.870154 & 0.032347 & 26.900712 \\
\hline
\end{tabular}

Pola hubungan variabel dapat di lihat pada gambar 2 berikut.

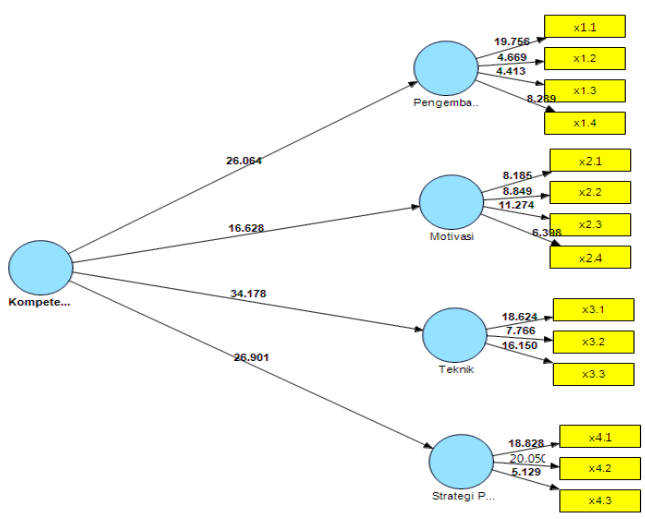

Gambar. 2. Model Hubungan Variabel Kompetensi Pelatih

b. Weight Relation. Hasil analisis diperoleh nilai R-square $\left(\mathrm{R}^{2}\right)$ untuk model variabel Kompetensi Pengembangan Karakter $\left(\mathrm{X}_{1}\right)$, Kompetensi Motivasi $\left(\mathrm{X}_{2}\right)$, Kompetensi Teknik $\left(\mathrm{X}_{3}\right)$ dan kompetensi Strategi Permainan $\left(\mathrm{X}_{4}\right)$ dapat dilihat pada tabel 4 berikut.

Tabel 4. Uji Evaluasi Model Struktural R-Square $\left(\mathrm{R}^{2}\right)$ 


\begin{tabular}{ccc}
\hline Variabel & Variabel Laten & R Square \\
\hline Kompetensi Pelatih $(\mathrm{X})$ & Pengembangan Karakter $\left(\mathrm{X}_{1}\right)$ & 0.754901 \\
& Motivasi $\left(\mathrm{X}_{2}\right)$ & 0.684405 \\
& Teknik $\left(\mathrm{X}_{3}\right)$ & 0.780531 \\
& Strategi Permainan $\left(\mathrm{X}_{4}\right)$ & 0.757169 \\
\hline
\end{tabular}

Hasil pembahasan dapat diketahui bahwa relevansinya semua indikator signifikan dalam merepresentasikan variabel kompetensi pelatih dan terdapat pengaruh yang signifikan antara kompetensi pelatih dengan kompetensi pengembangan karakter, kompetensi motivasi, kompetensi teknik dan kompetensi strategi permainan.

\section{Evaluasi Product}

Berdasarkan hasil analisis data kuantitaf, Adanya hubungan dan pengaruh tersebut secara konseptual kompetensi pelatih sepakbola usia dini yang direpresentasikan kedalam empat variabel $\left(\mathrm{X}_{1}, \mathrm{X}_{2}, \mathrm{X}_{3}\right.$, $\mathrm{X}_{4}$ ) dikembangkan menjadi beberapa indikator kompetensi, secara konseptual dirumuskan menjadi tiga unsur kompetensi yang harus dimiliki pelatih yaitu sikap (afektif), pengetahuan (kognitif), dan keterampilan (psikomotor).

\section{Hasil Analisis Data Kualitatif}

Analisis data kualitatif dilakukan melalui kegiatan wawancara dan observasi kepada pelatih sepakbola usia dini di SSB asosiasi kabupaten/kota (askab/askot) PSSI Jawa Timur. Hasil wawancara dan obeservasi sebagai berikut:

\section{Evaluasi Context}

Berdasarkan hasil observasi melalui dokumen tertulis secara menunjukkan bahwa keberadaan pelatih, perlu dukungan dari pemerintah dan lembaga terkait. Dengan deminikian legalitas formal kompetensi pelatih yang diakui oleh pemerintah, asosiasi PSSI, KONI dan asosiasi SSB relevansinya dapat dijadikan dasar hukum kepercayaan masyarakat terhadap pelatih.

2. Evaluasi Input

Berdasarkan hasil observasi melalui dokumen tertulis pelatih sepakbola usia dini, indentifikasi pelatih menurut latar belakang pendidikan pelatih memiliki jenjang SLTA (SMA, SMK, MA) dan lamanya melatih rata-rata antara 5 s.d 10 tahun serta rata-rata sudah memiliki lisensi D berdasarkan kewenangan melatih dari Asosiasi PSSI. Dengan demikian dapat dikatakan bahwa latar belakang SDM pelatih sepakbola usia dini minimal memiliki kualifikasi akademik SMA/SMK/MA, lamanya melatih 5 s.d 10 tahun dan telah memiliki lisensi D sesuai kewenangan yang diberikan Asosiasi PSSI.

3. Evaluasi Process

Proses pelaksanaan evaluasi kompetensi pelatih melalui pendekatan kualitatif dengan cara mencermati dan memilah data yang dianalisis serta menginterpretasikan makna hasil analisis berdasarkan hasil wawancara kepada nara sumber melalui proses pengumpulan dan pengelompokkan data (data colllection), selanjutnya dilakukan reduksi data (reduction), penyajian data (display) dan dihasilkan rumusan simpulan yang meliputi komponen pengembangan karakter dinyatakan bahwa pelatih dalam mengembangkan karakter menjadi contoh (role model) dalam menanamkan sikap disiplin, fair play, sportivitas dan saling menghargai kepada siswanya. Selanjutnya pada kompetensi motivasi pelatih memiliki perilaku percaya diri, mental bertanding, harga diri dan keyakinan serta rasa kebersamaan kepada siswanya selama melatih. Kemudian pada 
kompetensi teknik pelatih mampu mengajarkan teknik bermain sepakbola dengan memberi contoh gerakan teknik dasar bermain sepakbola, mengoreksi kesalahan teknik dasar bermain sepakbola dan menilai keterampilan gerakan teknik dasar bermain sepakbola dan kompetensi strategi permaianan, pelatih harus dapat mengembangkan kemampuan bermain sepakbola, menilai dan memonitor kemampuan siswa yang dilatih, menjelaskan taktik dan pola bermain sepakbola serta mengembangkan dalam bentuk bermain ( game) permainan sepakbola yang sebenarnya.

4. Evaluasi Product

Hasil verifikasi data berdasarkan kajian teoritis dan analisis deskripsi data, ditemukan bahwa persepsi pelatih sepakbola usia dini secara dekriptif sebagai berikut:

a. Seorang pelatih sepakbola usia dini harus dapat mengembangkan dan memiliki sifat nilai-nilai karakter seperti disiplin, sportif, jujur dan saling menghargai sebagai cerminan teladan bagi siswanya.

b. Seorang pelatih sepakbola usia dini harus memiliki motivasi yang mencakup kepercayaan diri, kemampuan mental bertanding, harga diri, keyakinan, dan rasa kebersamaan yang dapat memberikan semangat pada siswanya.

c. Seorang pelatih sepakbola usia dini harus memiliki kemampuan kompetensi teknik dasar keterampilan bermain bola, mengoreksi kesalahan bermain bola dan memahami teknik dasar bermain sepakbola sehingga dapat dijadikan model bermain sepakbola bagi siswanya.

d. Seorang pelatih sepakbola usia dini harus memiliki kompetensi strategi permainan yang dapat menganalisa kelemahan dan kekuatan lawan, strategi pertandingan, dan situasi pertandingan yang dapat dijadikan bahan materi bermain sepakbola.

Hasil verifikasi temuan yang dihasilkan secara konseptual berupa gambaran kompetensi yang harus dimiliki pelatih sepakbola usia dini dikembangkan menjadi tiga unsur yaitu sikap pelatih (afektif), pengetahuan pelatih (kognitif) dan keterampilan pelatih (Psikomotor)

\section{Deskripsi Evaluasi Context Kompetensi Pelatih}

Data dan informasi yang diperoleh dari beberapa pelatih SSB, pola pengembangan kompetensi pelatih sepakbola usia dini keberadaannya memerlukan legalitas dukungan dari pemerintah dan lembaga terkait seperti Asosiasi PSSI, KONI dan Asosiasi SSB. Keberadaan kompetensi pelatih dalam pengembangan sangat tergantung pada kinerja pelatih di SSB. Penguasaan dan pemahaman pelatih terhadap materi latihan tidak cukup untuk dijadikan andalan bila tidak didampingi dengan beberapa keahlian lain. Keahlian lain ini berkaitan dengan pemahaman mengenai metode latihan, keterampilan dalam melatih dan memahami kapasitas atlet yang dilatihnya, sehingga isi atau materi latihan yang akan dilatihkan merupakan gabungan bidang ilmu sebagai sumber bahan latihan yang secara utuh diperlukan untuk mencapai target yang telah diprogramkan oleh pelatih. Berbagai kajian menunjukkan bahwa salah satu orang yang paling berpengaruh dalam pengalaman olahraga bagi atlet adalah pelatih dan lingkungan kontekstual yang diciptakan oleh pelatih (Bartholomew, Ntoumanis \& Thogersen, 2010).

\section{Deskripsi Evaluasi Input Kompetensi Pelatih}

SDM pelatih sebaiknya mempunyai kompetensi dasar yang terkait dengan pendidikan pelatih. Untuk menunjang keberhasilan pelatih di bidang kepelatihan sebaiknya pelatih mempunyai pendidikan secara formal yang terkait bidang yang akan ditekuni. Pelatih yang menangani SSB rata-rata memiliki latar belakang pendidikan formal mulai dari jenjang SMA sampai dengan perguruan tinggi dan rata-rata lamanya melatih antara 5 - 10 tahun serta memiliki kualifikasi lisensi sebagai pelatih sepakbola yang disyaratkan oleh Asosiasi PSSI, hal ini terbukti bahwa hampir rata-rata SSB memiliki pelatih yang berlisensi D dan C. Kenyataan itu tidak cukup, tentunya pelatih harus pula 
meningkatkan kemampuannya dengan jalan mengikuti penataran-penataran, pelatihan dan kursuskursus yang terkait dengan persyaratan penunjang kinerja pelatih. Pada umumnya untuk meningkatkan pengetahuan dan kualitas SDM pelatih tentang ilmu kepelatihan tersebut biasanya di wadahi oleh asosiasi SSB di daerah masing-masing dengan menyelenggarakan kursus-kursus kepelatihan yang relevan, berlisensi dan bersertifikasi.

\section{Deskripsi Evaluasi Process Kompetensi Pelatih}

Berdasarkan hasil paparan data secara kuantitatif dan kualitatif, standar kompetensi yang dihasilkan dalam penelitian ini berupa perubahan kinerja pelatih yang terkait empat komponen kompetensi secara deskriptif meliputi:

\section{Kompetensi Pengembangan Karakter}

Mengembangkan karakter dapat dilakukan dengan berbagai cara, hasil kajian penelitian Doty (2006) bahwa karakter dapat diajarkan dan dipelajari dalam suasana olahraga. Berolahraga dapat membangun karakter, bila lingkungannya terstruktur dan ada tujuan serta direncanakan untuk mengembangkan karakter (p.1-20). Makna yang terkandung pada konsep tersebut bahwa membangun karakter bukan sebatas berolahraga namun dalam rangka menanamkan nilai-nilai yang ada dalam olahraga harus direncanakan (didesain) terlebih dahulu agar siswa memahami apa tujuan dan maksudnya. Pelatih merancang program serta membangun suasana karakter dalam proses pembelajaran sepakbola yang hasilnya dari akan terlihat pada saat pertandingan. Mengembangkan nilai-nilai karakter memerlukan kajian lebih mendalam karena dari beberapa pilar karakter masingmasing masih dikembangkan lagi berdasarkan sifat karakter. A person of charakter embodies both performance character and moral character (Mathew. 2004). Berdasarkan sifatnya karakter terbagi menjadi dua yaitu karakter kinerja (performance) dan karakter moral. Rudd dan Mondello (2006) definitions of character produced two major themes: one related to moral character and the second social character (p.1-10). Hasil kajian dan analisis dalam penelitian ini secara deskriptif bahwa nilai karakter pada tataran tertentu dilakukan pelatih dalam rangka memotivasi siswa, misalnya kebiasaan pelatih datang tepat waktu ketempat latihan, selalu berdoa sebelum dan sesudah latihan, tidak pernah meninggalkan tempat latihan sebelum waktunya. Perilaku pelatih tersebut mencerminkan sikap disiplin dan sportif, fair play, dan saling menghargai.

2. Kompetensi Motivasi

Dalam kehidupan sehari-hari tingkah laku manusia tidak lepas dari motivasi. Motivasi pelatih SSB dalam proses pembinaan pemain di SSB tidak lain karena menyalurkan hobinya yang rata-rata sebagai mantan pemain sepakbola, dorongan rasa senang, dan adanya kepuasan tersendiri sehingga tidak terpikir besar kecilnya bentuk imbalan yang diterima. Peran pelatih sebagai agen pembelajaran (learning agent) adalah seorang pelatih sebagai fasilitator, motivator dan pemberian insprirasi berlatih bagi siswanya. Sebagai motivator, pelatih harus mampu membangkitkan motivasi latihan bagi siswanya dengan memperhatikan prinsip-prinsip memiliki minat dan perhatian terhadap pekerjaannya, memberikan tugas yang mudah dimengerti dan memberikan penghargaan terhadap hasil kinerja dan prestasi siswanya. Dari paparan tersebut, motivasi yang harus dimiliki para pelatih usia dini dalam melakukan proses pembelajaran di SSB menggambarkan hal-hal yang terkait kepribadian pelatih dalam menanamkan dan membantu percaya diri, harga diri dan keyakinan, mental bertanding dan rasa kebersamaan yang timbul dalam diri pelatih (motivation internal) tanpa rangsangan atau bantuan orang lain.

\section{Kompetensi Teknik}

Kemampuan teknik pelatih sepakbola usia dini sangatlah penting peranan dan tanggungjawabnya karena siswa yang dilatih merupakan siswa berusia dini ( 8 - 12 tahun) yang merupakan usia emas 
(golden age). Pelatih harus memberikan latihan keterampilan teknik dasar bermain sepakbola dengan baik dan benar, karena bila salah memberikan contoh teknik dasar bermain sepakbola akan terus terbawa sampai dewasa. Proses pembelajaran pada anak usia dini merupakan periode dasar pembinaan yang sangat strategis karena di usia dini merupakan periodesasi pertama dalam sebuah rangkaian pembinaan siswa secara sistimatis, terarah, bertahap, berjenjang dan berkesinambungan. Disamping itu proses pembelajaran di usia dini merupakan usia dimana siswa pertama kali dikenalkan pada keterampilan teknik dasar bermain sepakbola yang meliputi: perasaan dengan bola (ball feeling), menggiring bola (dribbling), mengoper bola (passing), menghentikan bola (controlling), menendang bola ke arah gawang (shooting), menyundul bola (heading), menyerang (attacking), bertahan (defending), dan menjaga gawang (goal keeping) dengan baik dan benar (Sneyers. 1988). Berdasarkan hal tersebut, pelatih harus memiliki kompetensi teknik berupa pengetahuan teknik dasar permainan sepakbola yang meliputi pemahaman dan penguasaan keterampilan teknik dasar bermain sepakbola dengan baik dan benar sehingga memungkinkan siswa untuk mampu melakukan dan mempraktekkan beberapa teknik dasar bermain sepakbola yang diajarkan. Oleh karena itu pemahaman teknik dasar bermain sepakbola perlu diajarkan kepada siswa sebagai pondasi yang melandasai dasar-dasar bermain sepakbola dengan baik dan benar.

4. Kompetensi Strategi Permainan

Ketepatan dalam menjalankan suatu strategi tergantung pada formasi pemain yang disesuaikan dengan kemampuan dan penguasaan keterampilan dasar bermain sepakbola yang dimiliki oleh para pemain. Strategi merupakan pendekatan secara menyeluruh yang berkaitan dengan perencanaan yang sudah ditetapkan sebelumnya. Sedangkan taktik merupakan siasat yang dirancang dan dilaksanakan dalam suatu permainan. Strategi mengacu pada gerakan-gerakan yang dibutuhkan dalam suatu pertandingan dan fungsinya sebagai pendukung taktik dalam bertanding. Dengan demikian antara strategi dan taktik memiliki makna yang berbeda, akan tetapi dalam pelaksanaannya kedua istilah tersebut saling terkait satu sama lain untuk mencapai tujuan yang sama yaitu memenangkan pertandingan. Memperhatikan fakta di lapangan dan dari hasil pengamatan menunjukkan bahwa gambaran pelatih pada saat menerapkkan strategi permainan sepakbola sangat dipengaruhi oleh dasar-dasar bermain sepakbola. Dasar-dasar bermain sepakbola tersebut meliputi keterampilan ( $k$ kill) bermain sepakbola, kondisi fisik dan Pengetahuan (kecerdasan dan daya ingat). Untuk itu tuntutan seorang pelatih harus paham betul tentang strategi permainan terutama sekali dalam memahami kekuatan dan kelemahan lawan, mengevaluasi setiap hasil strategi pertandingan yang diterapkan dan bagaimana menerapkan variasi strategi menghadapi lawan tanding yang berbeda-beda kondisinya.

\section{Deskripsi Evaluasi Product Kompetensi Pelatih}

Seorang pelatih yang memiliki kompetensi adalah pelatih yang bisa memberikan dan menyampaikan ilmu pengetahuannya kepada siswa yang di latih, serta memperlihatkan dan memperagakan teknikteknik kepada atletnya agar siswa tersebut bisa melakukan teknik-teknik dengan baik dan benar. Kompetensi pelatih sepakbola usia dini yang terdiri dari kompetensi pengembangan karakter, kompetensi motivasi, kompetensi teknik, dan kompetensi strategi permainan kemudian dikembangkan menjadi beberapa indikator kompetensi yang harus dimiliki dan disyaratkan.

Hasil kajian evaluasi, gambaran kompetensi pelatih sepakbola usia dini terbagi menjadi tiga unsur yaitu 1) Sikap (afektif) yang meliptui kompetensi pengembangan karakter (sikap disiplin, sportif, pair play, saling menghargai), dan kompetensi motivasi (percaya diri, mental bertanding, harga diri dan keyakinan, kebersamaan)., 2) Pengetahuan (kognitif) meliputi kompetensi teknik (memperagakan teknik, mengoreksi teknik, mengenali kemampuan siswa) dan 3) keterampilan (psikomotor) meliputi kompetensi strategi permainan (mengetahui kelemahan dan kekuatan lawan, 
strategi pertandingan, mengenal situasi pertandingan). Ketiga unsur tersebut merupakan kompetensi paling mendasar yang harus dimliki pelatih sepakbola untuk dijadikan landasan rumusan kompetensi pelatih sepakbola usia dini yang meliputi sikap, pengetahuan dan keterampilan. Hasil tersebut diperjelas oleh pendapat Broke \& Stone dalam Osman (2007) menyatakan; "Inti dari pengertian kompetensi yang dipahami selama ini adalah mencakup penguasaan terhadap 3 jenis kemampuan, yaitu: sikap perilaku (attitude), pengetahuan (knowledge, science) dan keterampilan teknik (skill, teknologi).

\section{KESIMPULAN}

Hasil analisis data kuantitatif dan kualitatif dengan menggunakan model evaluasi CIPP secara deskriptif terdiri dari:

1. Context. Hasil analisis menyatakan bahwa keberadaan pelatih yang memilki legalitas dapat dijadikan landasan hukum kepercayaan masyarakat terhadap kompetensi pelatih.

2. Input. Hasil analisis menyatakan bahwa latar belakang SDM pelatih sepakbola usia dini untuk menunjang kompetensinya minimal memiliki kualifikasi akademik pendidikan jenjang SMA/ SMK/MA, lamanya pengalaman melatih 5 s.d 10 tahun dan telah memiliki lisensi D sesuai kewenangan yang diberikan Asosiasi PSSI.

3. Process. Hasil analisis menyatakan bahwa: a. kompetensi pengembangan karakter merupakan pondasi yang sangat mendasar dalam membentuk nilai-nilai kepribadian pelatih yang harus diterapkan dalam proses pembelajaran bermain sepakbola. b. kompetensi motivasi merupakan motivasi yang harus dimiliki dan dikembangkan dalam proses pembelajaran sepakbola pada siswanya. c. kompetensi teknik merupakan penguasaan keterampilan bermain sepakbola yang harus dimiliki oleh setiap pelatih dan dikembangkan dalam proses pembelajaran sepakbola pada siswanya dan d. kompetensi strategi permainan dalam proses pembelajaran bermain sepakbola mampu menerapkan dan mempraktekan bentuk strategi permainan di lapangan dalam suasana permainan yang sebenarnya.

4. Product. Hasil analisis menyatakan bahwa kompetensi pelatih sepakbola usia dini ada hubungan dan pengaruhnya dengan kompetensi pengembangan karakter, kompetensi motivasi, kompetensi teknik dan kompetensi strategi permainan. Adanya hubungan dan pengaruh tersebut adalah gambaran kompetensi yang harus dimiliki pelatih sepakbola usia dini secara konseptual kompetensi pelatih sepakbola usia dini direpresentasikan oleh 4 variabel dan dikembangkan menjadi rumusan kompetensi yang harus dimiliki pelatih sepakbola usia dini di sekolah sepakbola (SSB). Landasan kompetensi pelatih tersebut secara konseptual terdiri dari: unsur sikap (afektif), pengetahuan (kognitif), dan keterampilan (psikomotor).

\section{DAFTAR PUSTAKA}

Afta Mylsidayu. (2011). Pengembangan Model Tes Keterampilan Bola Basket untuk Anak Usia 10-12 tahun. Jurnal IPTEK Olahraga, ISSN:1411-0016. 13(1), 1-19.

Armandi John, (2008). Kontribusi Motivasi Berprestasi dan Disiplin Kerja Terhadap Kinerja Pelatih, Jurnal IPTEK Olahraga. ISSN:1411-0016. 10(2), hlm. 97-111.

Bartholomew, K.J., Ntoumanis, N., \& Thogersen, Ntoumanis, C. (2010). The Controling Interpersonal Style In A Coaching Contex: Development and Initial Validation of A Psychometric Sclae., Journal of Sport \& Exercise Psychology. 32(2), ), hlm. 193-216.

Boyatzis, Richard E. (2008). A Competencies in The 21st Century. Journal of Management Development. ), hlm. 271, 5-12.

Dalton, C Jon, 2006. Integrating Sport into College Life and Learning: An Interview with Larry Shim, Pressident of Berea College, Journal of College and Character, 7(3), ), hlm. 1-3. 
Davidson, Mathew, (2004). Developing Performance Character and Moral Character in Youth, The Fourth and Fifth Rs Respect and Responsibility, Journal of College and Character. 10(2). ), hlm. 1-6.

Doty Joseph, (2006). Sport Building Character., Journal of College and Character. 7(3), ), hlm. 1-20.

Feltz, D.L., Chase, M.A., Moritz, S.E., \& Sullivan, P.J. (2008). A conceptual model of coaching efficacy: Preliminary investigation and instrument development. Journal of Educational Psychology. 91(1), ), hlm. 765-776.

Federation Internationale de Football Association., (2015). FIFA World Rangkings. Diunduh 5 Nopember dari http://www. fifa.com.

Hari Setijono, (2006). Materi Pelatihan Pelatih Pusat Pendidikan dan Latihan Olahraga Pelajar (PPLP), Jakarta : Kementerian Negara Pemuda dan Ola hraga Republik Indonesia.

Hardy, J. Charles. Burke, L. Kevin. \& Crace Kelly, R. (2013). Coaching: An Effection Communication System. Journal Sport Psyschology. 46(2), ), hlm. 112-134.

Imam Syafii., \& Mahfud Irsyada, (2011). Evaluasi Penyelenggaraan Liga Pendidikan Indonesia, Jurnal IPTEK Olahraga, ISSN:1411-0016. 13(1), hlm. 40-55.

Iskandar, (2013). Metodologi Penelitian Pendidikan dan Sosial. Jakarta: Penerbit Referensi

Johar Arifin (2013), Kompetensi Pelatih Sepakbola Usia Dini. Berita Sore diunduh tgl 8 Nopember dari http://www. BinaSepakbola. com.

Kresten., Vol D. Dieffenbach., Melissa Murray., \& Rebecca Zakrajsek. (2011). The Coach Education Internship Experience: An Exploratory Study. International Journal of Coaching Science. 5(2), hlm. 3-25.

Lickona T., (2011), The Content of Our Character: Ten Essesial Virtues, The Fourth and Fitth Respect and Responsibility. Journal of College and Character., 10 (1), hlm. 1-6

M. Haris Satria. dkk. (2012). Evaluasi Program Pembinaan Olahraga Sepakbola di Sekayu Youth Soccer Academy (SYSA). Journal of Physical Education and Sport, ISSN 2252-6412. 1(2), hlm 161-166.

Murray, Peter. (2003). Organizational Learning, Competencies, and Firm Performance: Emperical Observations, The Learning Organization, International Journal of Coaching Science. 10(2), hlm . 305-313.

Monty P, \& Satriadarma, (2012), Psikologi Olahraga \& Psikologi Latihan. [Web log post] diunduh 10 Februari dari http://himpsi. web.id. 42421. Master web.net/publikasi. 0001.php

Moleong., J. Lexy. (2010b). Metodologi Penelitian Kualitatif. Edisi Revisi, Bandung: Remaja Rosda Karya.

Philips., Michael B. (2007). Student Athlete Perceptions of Head Mens Basket Ball Coaching Competecies at 15 Selected NCAA Division II Cristian Colleges. Murfresboroo: Faculty of Graduate School at Middle Tennesse State University.

PSSI, (2012). Pedoman Pembinaan Sepakbola Nasional. Jakarta: Pengurus Besar Persatuan Sepakbola Seluruh Indonesia.

Robert M. Malina., Joey C. Eisenmann, Sean P. Cumming., Basil Riberio., \& Jolio Aroso., (2004)., Maturity-associated variation in the growth and fungsional capacities of youth football (soccer) players 13-15 years., Journal Appl Physiol, 91 (10), hlm.555-562

Rudd Andy \& Mondello J. Michael., (2006)., How do College Coaches Define Character A Qualiitative Study with Division IA Head Coaches., Journal of College and Character., 7(3), hlm.1-10.

Shafiei M., \& Goodarzi, M. (2009). Determining National Coaches Selection Criteria in Swimming, Diving, and Water Pol by Coaches Viewpoint, World Journal of Sport Science. 2(4), hlm. 241247.

Smith, RE., \& Smoll, F.L., (2012). Way to Go, Coach A Scientifically proven Approach to Coaching Effectiveness (2nd eds), Portola Valley, CA:Wande

Spencer Lyle M. and Signe M. Spencer. (1993a). Competency Assessment Methode. USA: Addison Wesley Publishing Inc.

Sofia Santos., Isabel Mesqueta., Amando Gracia. \& Antonio Resado. (2010). Coaches Perception of Competence and Acknowlegment of Training. Journal of Sport and Medicine. 9(2), hlm. 62-70. 
Soegijono. dkk. (2009). Pedoman Pembinaan dan Pengembangan Olahraga Usia Dini. Jakarta: Ditjen Dikdasmen Departemen Pendidikan Nasional.

Sugiyono. (2012). Metode Penelitian Pendidikan, Pendekatan Kuantitatif, Kualitatif dan R\&D. Cetakan Ke 14. Bandung: Alfabeta.

Tuncel, D.S., (2009). A New Scale Measuring Coaches Unethical Behaviors for Comparison by Gender, Age, and Education Level of Coach., Journal.International Review of the Sociology of Sport., 24(2), hlm. 151-161

Wen-wen Ho., Wei Jen Chen., \& Chih Chou (2011). Evaluation of the Suicide Prevention Program in Kaohsiung City, Taiwan Using the CIPP Evaluation Model., Journal Community Ment Health., 47 (1) hlm. 342-350

Wirawan. (2012). Evaluasi, Teori, Model, Standar, Aplikasi, dan Profesi, Rajawali Press. Divisi Buku Perguruan Tinggi. Jakarta: PT Raja Grafindo Persada.

Yusuf Hidayat \& Sukadiyanto. (2012). Instrumen Strategi Multiteknik Mental Atlet Usia 11 - 13 Tahun. Jurnal IPTEK Olahraga. ISSN:1411-0016. 14(3), hlm. 268 - 287. 